\title{
FOREIGN CONVICTS EXECUTION: CRIMINAL JURISDICTION BENEATH INTERNATIONAL TENSION
}

\author{
Tajudin dan Solihin Niar Ramadhan \\ Faculty of Law, Padjadjaran University. \\ Email: i.tajudin@yahoo.com
}

\begin{abstract}
The existence ofthe death penalty remains a controversial issue in several countries around the world. Although many countries have abolished the death penalty in its criminal law system, Indonesia still retainsthe capital punishment within its criminal law policy.In Practice, theexecutionhasbeen implemented long agodespite the fact that it leaves a lot of problems. There are many reactions from other countries when prosecutors process to execute foreign nationals. On fact, many head of state request to president of Republic of Indonesia to change the punishment or give forgiveness.This journal will discuss the main problemsencountered in the implementation of the death penalty in Indonesia. The problems are: Firstly, the imposition of the death penalty for foreign nationals in order to implement the national jurisdiction underinternational community's pressure. Secondly, the postponement of death sentence associated with the theory of retribution and human rights.
\end{abstract}

Keyword: The death penalty, retribution theory, human rights.

\section{A. INTRODUCTION}

What is the indicator of someone who deserves to be sentenced todeath? If capital punishment was applied, would people be complacent andthe crime rateentirely decrease? If the death penalty was abolished, would Indonesia receivea title as 'friendly country of human rights' from international community? Over the years, these questions always become the sourceof debate on urgency of capital sentence.

It is unquestionably true that the imposition of death penalty in Indonesia is mostly debatable. Several academics and practitioners, especially human rights activists argue that death penalty has completely violatedbasic human rights, namely the right to life. Others believe that it is one of effective ways to deter and tackle crime. Although Indonesia constitutionally upholdshuman rights,practice 
ofdeath penalty is still maintained with hope of providing psychological effects for society.

Indonesia still maintains death penalty in its criminal law policy. Death penaltyis clearly set as a principal punishment stated in Article 10, Indonesian Penal Code.Severalactivitieswithin the Penal Code arepunishable by death penalty. In addition, some classifications of activitiesare also contained in various regulations, such as in: the Emergency LawNumber 12/1951on Firearms and Explosives, the Law Number 26/2000on Human RightsCourt, the Law Number $31 / 1999$ on the Eradication of Corruption, the Law Number 15/2003on Combating Terrorism, or the Law Number 35/2009 onNarcotics.

In practice, the implementation of death penalty in Indonesia, as many as 77 convicts have been executed successfully since 1979 until July 29, 2016(Compiled from various sources).KontraS claimed that this information was inaccurate due to the lack of public disclosure related to death penalty, particularly in the new order era between 1966 and 1998 (Badan Pekerja KontraS, 2007:22). The composition of death row inmates who have successfully been executed, consists of:murderer (23), political perpetrators (25), terrorist (6), drugs abusers (23). Based on the fact that the convicts of narcoticshave dominated in executions over the last 5 years.Unfortunately, as many as 50 death row inmates (most of their status as foreigners)wholly involved narcotics case, have not been executed.

Execution against foreigners always causesmany problems. The problems have largely been identified, such as:International pressure to abolishdeath penalty, intervention of foreign countries, diplomatic relations between countries, or government's consistency on implementing death penalty.

International community urges Indonesia to abolish death penalty. For instance, when the European Unionattempted to influence Indonesian government to abolish death penalty in the new draft of PenalCode. TheEuropean Union'sinfluence was proposed byMarkkuNilnloja (the Ambassadorof Finland), Joachim BroudreGroger (the Ambassador of Germany), and Ulrich Eckle (the 
Delegation of EU Commission). As an effort to reduce the pressure, on October $28^{\text {th }}, 2005$ Indonesia officially ratified the International Covenant on Civil and Political Rights (ICCPR). However, hithertoIndonesia has not ratified the Second Optional Protocol to the International Covenant on Civil and Political Rights Aiming to the Abolition of the Death Penalty (CCPR-OP2-DP). Despite the pressure ofinternational community, Indonesia is still implementingdeath penalty within its criminal law system.

Other issues such as intervention of foreign countries and deterioration of diplomatic relations occurred prior to executions of Australian nationals, members of the 'Bali Nine', Andrew Chan and MyuranSukumaran. Australian Prime Minister Anthony John Abbott denounced the execution. He mentioned about Australian humanitarian assistance for helping tsunami victims in Aceh, 2004. In terms of diplomatic relations, the Australian Foreign Minister Julie Bishop threatened to boycott Indonesia and withdrawthe Australian embassy in Jakarta. At the same time, the Netherlands also recalled its ambassador after Foreign Secretary Albert Gerard Koenders considered that the execution of their citizen, AngKiemSoe, as a denial of dignity and integrityof human being.

Execution of Filipino, Mary Jane Fiesta Veloso tests thegovernment's consistency in carrying out death penalty. Mary Jane was arrested, tried, and sentenced to death in 2010 after being convicted of narcotics smuggling approximately 2.6 kilograms of heroin into Indonesia. However, thegovernment had twice postponed the execution of Mary Jane Veloso because of comprehensive assessment. At the time, the governmentrespects ongoing judicialexamination in the Philippines. Hitherto, the Philippines government still needs Mary Jane as witness of human trafficking case afterMaria Kristina Sergio (suspected as recruiter of Mary Jane)surrendered to the Philippines police.

Based onfacts, capital punishment is still a serious metter, especially for executing foreign convicts. Two major problems being faced by Indonesia, have successfully been identified: Firstly, the imposition of death penalty for foreigners in Indonesiain capacity to implement criminal jurisdiction. Secondly, the 
postponed executionwhich is researchedusing both the theory of retribution andhuman rights scope.

\section{B. RESEARCH METDHODS}

These problems are analyzed using normative analysis in juridical method. The analysis is based on theory, principles, related with regulations, doctrine, and comparative approach.

\section{DISCUSSION}

\section{Criminal Jurisdiction as a Reflection of Sovereignty}

Indonesia as a state of law (rechtstaat) embraces the sovereignty of the people. As stated in Article 1 (2)the Constitution of the Republic of Indonesia, "Sovereignty is in the hands of the people and carried out in accordance with the Constitution". Then, in Article 1 (3) the Constitution stated that Indonesia is the state of law (rechstaat), not the state of power (machtstaat). Thus, both of these articles mean thatapplicable law is entirely derived from the sovereignty of the people.

All countries have sovereignty. According to Jean Bodin, sovereignty implies a power that is original (the highest power is not derived from any other authority); Highest (there is no power that can limit its power); immutable and eternal; cannot be broken; and cannot be transferred or assigned to another entity (Yudha Bhakti, 1999:41-42). Based on that meaning,sovereign state can probably be definedas a state that does not recognize any other authority (Mochtar Kusumaatmadja \&Etty R. Agoes, 2010:17). Moreover, the meaning has causedmisunderstanding that the sovereignty of a country is limitless. Unfortunately, these ideas have led to wrong thought regarding the sovereignty of a country in conjunction withinternational community.

Clarifying restrictions of a state's sovereignty, C.F Strong(1966:80) explained that the concept of supreme powercan be internal within a country (sovereignty in astate), and can also be external (sovereignty of a state). SupportingStrong's argument, MochtarKusumaatmadjastated that sovereignty as the supreme authority contains two important limitations: The poweris limited 
by state's borders; andthe power ends in which another state's power begins(Mochtar Kusumaatmadja \&Etty R. Agoes, 2010:18). Based on these limits, it can be mentioned that the highest power is restricted by state's boundary. This arguments is referred as territorial sovereignty, the sovereigntyowned by a country by implementing its exclusive jurisdiction on their territory (Huala Adolf, 1996:99).

Theoretically, jurisdictionas a reflection of a state's sovereignty is carried out within its boundaries (Sigid Suseno, 2011:54). Incontext of criminal law, according to B. James George Jr., jurisdiction contains state's power to define criminal law, regulatory lawand law enforcement through administrative and judicial actions (Sanford H. Kadish, 1983:922). In order to limit its scope, RomliAtmasasmita(1997:89) distinguishes three concepts of different jurisdiction: (a)jurisdiction to enact a legislation (jurisdiction to prescribe); (b) jurisdiction to conduct prosecutions (jursidiction to adjudicate); (c)jurisdiction to apply the rules of law (jurisdiction to enforce).

Indonesia as a state of law that adheres to sovereignty of itspeople, has the law-making jurisdiction(jurisdiction to prescribe). Constitutionally, it is described in Article 20 paragraph (1), "The House of Representatives holds the power to make laws." Then, in paragraph (2),stated that"Everylegal draft is discussed by the House of Representatives and President for approval together.'Thus, laws regulating death penalty, is philosophically as the result of -a jointagreementbetween the people and the rulers.

BardaNawawiAriefargues that the implementation of the jurisdiction to prescribe may likely vary and even clash between one country and another,then it causes many problems in its application (Sigid Suseno, 2011:57). Implementation of jurisdiction to prescribe is closely related to a criminal policy, in particular by means of penal system (criminal law). Two central issues in the criminal policy using penal means, are generally identified: Whatelements of actions that should beconsidered as criminal offense; and whattypes of penalsanctions that should be appropriately used or charged to the offender (Barda Nawawi Arief, 2011:30).If 
capital punishment belongs to the second issue, a question is, whatactivities should be regulated as criminal offense and sentenced to death? To answer the questions, firstly, it is obviously necessary to make a comprehensive analysis ofInternational Covenant on Civil and Political Rights 1966 (ICCPR). Then, the analysis must be directlyconnected with national legal instruments which arecontaining death penalty. In addition, aims of the analysis are not only todetermine what kind of actions that deserve to be sentenced to death, but also to scrutinize the implementation of criminal jurisdiction.

The first analysis is based on international legal instruments: International Covenant on Civil and Political Rights (ICCPR).Article 6, paragraph (2) of the ICCPR stipulates that:

"In countries which have not abolished the death penalty, sentence of death may be imposed only for the most serious crimes in accordance with the law in force at the time of the commission of the crime and not contrary to the provisions of the present Covenant and to the Convention on the Prevention and Punishment of the Crime of Genocide. This penalty can only be carried out pursuant to a final judgement rendered by a competent court."

Based on this article, the death sentence may only be imposed on some of 'the most serious crimes'. Furthermore, whatis the indicator of 'the most serious crimes'? It can possibly be justified if the phrase is based on Article 5 of the Rome Statute of the International Criminal Court. However, keep in mind that the phrase 'the most serious crimes' are completely held together with the following phrase which asserts, "in accordance with the law in force at the time of the commission of the crime'. Therefore, it can be clearly interpreted that the indicators of 'the most serious crimes' must be based on the perspective of positive law of each state, where the crime occurred.

The following question is, how the implementation ofjurisdiction to conduct prosecutions (jursidiction to adjudicate) and the jurisdiction to apply the rules of law (jurisdiction to enforce) is practically applied to the crime? Based on the articleabove, death penalty can only be carried out pursuant to a final judgementrendered by a competent court. The court may have authorities to 
examine a case and penalize the perpetrator(s)if the criminal actis committed and perfectly done within its jurisdiction. On this fact, each state party has jurisdiction in carrying out the death sentence with a condition: the state has to determine the types of 'the most serious crimes'in their positive law; and the sentence must be handed down by a competent court.

The second analysis is based onnational legal instruments that impose the death penalty as principal punishment. Legally, there is no law stating explicitly that the offenses being regulated is a serious offence or ordinary crime. Then, how can we know the indicators of serious crimes in perspective of national law? Applying the interpretation of Article 6 paragraph (2) ofICCPR, can be compared to that indicator of serious crimes in the perspective of national law. Itrefers to a kind of sanction imposed, i.e the death penalty. On the other hand, another indicator is an impact of that crime against social, economic, and cultural value in society entirely. Based on these indicators, national law instruments which can bea sourceof analysis are the Law Number 26 / 2000 on Human Rights Court and Law Number 22 / 1997 as amended into Law Number 35/ 2009 on Narcotics.

The Law onHuman Rights Court is strongly attractive to be analyzed because violations of human rights have always been the object of attention, both innational and international jurisdictions. In Indonesia, crimes against human rights are considered as a seriouscrime. As evidence, based on Article 36 and Article 37 of the law, the death penalty can be imposed for crimes of genocide and crimes against humanity. Compared with Article 77 of the Rome Statute, the similar crimescan not be sentenced to death, butmaximumof 30 yearsimprisonment or life imprisonment. In terms of jurisdiction,the International Criminal Court has authority to try for thesecrimes thoughtheyhave to respect theexhaustion of local remedies' principle at first (http://hrlibrary.umn.edu/svaw/law/un/exhaustion.htm, accessed 26 September 2016). If itwas analyzed using universal principle, the Law on Human Rights Court would be enforced against such crimes. It is clear that the imposition and the execution of death sentenceon crimes of genocide and crimes against 
humanity is a reflection of the sovereigntyof Indonesia, based on thewillingness and the ability ofthe state (the government).

Death penalty is generally imposed oncase of narcotics. The second comprehensive analysis will be focused on types of activities and death sentenceon theLaw Number 22 / 1997 on Narcotics (Narcotics Law). Everyone who is legally and convincingly violating the provisions of Article 80 paragraph (1)a, Article 80 paragraph (2)a, Article 80 paragraph (3)a, Article 81 paragraph (3)a, Article 82, paragraph (1)a, Article 82, paragraph (2)a, and Article 82 paragraph (3)a will expressly sentenced to the death penalty. This legislation has beenproducing manydeath row inmates in Indonesia, especially those who are foreign nationals. Unfortunately, the law was not relevant to situation and condition at the following time. Consequently, it was declared as invalid regulation and amended by the Law Number 35 / 2009 on Narcotics (Narcotics Law). Nevertheless, the death penalty is still regulated as principal punishment to some classifications whichare considered as serious offences. Death sentence is given to everyonewho legally and convincingly violates the Article 113 paragraph (2), Article 114 paragraph (2), Article 116 paragraph (2), Article 118 paragraph (2), Article 119 paragraph (2), Article 121 paragraph (2), and Article 113 paragraph (1) of the Law on Narcotics.

Human rights crimes are categorized as crimes within the jurisdiction of the International Criminal Court, on the opposite,narcotic crimesare not an international crime. Although the UN Human Rights Commission found those crimes (related to drugs) are not included in 'the most serious crimes', Constitutional Court Justice I DewaGedePalguna stated that drugs abuse can be compared to "the most serious crime" in Indonesia (Judicial Review CaseNumber: 2/PUU-V/2007 andCase Number: 3/PUU-IV/2007, 2007:52). Based on this opinions,selection of the death penalty as a sanction for drugs abusers is the right policy inperspective of the rule of law in Indonesia,in which views drugs abuse as a serious crime. In addition, the imposition of capital punishmentis not contrary to Article 6 paragraph (2) of ICCPR, since that article does not prohibit the death 
penalty. As consequence, in order to protect the national interests, the death penaltywill be retained properly in the national criminal justice system.

The implementation of capital punishment for they bothdomestic and foreignconvicts of drugs abuse, is one of Indonesia's commitment toimplementthe United Nations Convention against Illicit Traffic in Narcotic Drugs and Psychotropic Substances 1998. Indonesia is a state party which officially participated by signing and ratifying the Convention (https://treaties.un.org/Pages/ViewDetails.aspx?src=TREATY\&mtdsg_no=VI-

19\&chapter=6\&clang=_en, accessed 20 September 2016). The Convention considered that the crime of drug abuse is particularlyserious, in condition of:

a. The involvement in the offence of an organized criminal group to which the offender belongs;

b. The involvement of the offender in other international organized criminal activities;

c. The involvement of the offender in other illegal activities facilitated by commission of the offence;

d. The use of violence or arms by the offender;

e. The fact that the offender holds a public office and that the offence is connected with the office in question;

f. The victimization or use of minors;

g. The fact that the offence is committed in a penal institution or in an educational institution or social service facility or in their immediate vicinity or in other places to which school children and students resort for educational, sports and social activities;

h. Prior conviction, particularly for similar offences, whether foreign or domestic, to the extent permitted under the domestic law of a Party.

Comparing with its elements, the convention only imposes sanctions either imprisonment or other forms of deprivation of liberty, fines and seizure of assets as far as can be proved as a result of the crime. In addition, the culprit can be punished usingtreatment, education, aftercare, rehabilitation or social 
reintegration. In terms of jurisdiction, Article 4 of the Convention provides authority to state parties to establish jurisdiction over the crimes committed in their region, on board a vessel flying its flag or an aircraft which is registered under its laws at the time.

In Indonesia, themisuse of narcotics occupies dominant position in executions over the last 5 years. On the fact, as many as 50 death row inmates were wholly involved narcotics cases have not been executed. In addition, most of their status as foreignertraffickers and smugglers. Although mostof them are foreigners, their criminal action occurred in Indonesia is obviously punishable bydeath sentence. Thus, de facto and de jure, territorial principle can beconfidently applied. For instance, in the 'Bali Nine' case. Andrew Chan had organized MyuranSukumaran, Renae Lawrence, Scoth Anthony Rush, Michael Will iamCzugaj, Matthew James Norman, Martin Eric Stephens, Tan DucThanh Nguyen, Si Yi Chen without rights and illegally export, offer for sale, distribute, sell, buy, deliver, receive, be an intermediary in the sale and purchase or exchangeof first category narcotics-as idenfitied as heroin- weighing approximately 8202 grams from Bali to Australia(The Supreme Court's Verdict Number 37 PK/Pid.Sus/2011, on behalf of the convict: Andrew Chan, 2011). They were arrested by police officers on April 17, 2005 in five different places in jurisdiction of Denpasar District Court. On these cases, it is clear enough that the locus delictihad been occurred in Indonesian territorial. Despite the intervention ofAustralian Prime Minister Anthony John Abbott and Australian Foreign Minister Julie Bishop, the execution of Andrew Chan and MyuranSukumaranwere running smoothly onthe second stage execution, April 29, 2015. Accordingly, as a reflection of Indonesian sovereignty, the execution has proved that death penalty for foreign convicts can notbe intervened by other states.

Based on the facts and the analysis above, it can be concluded that the imposition and execution of death sentences against foreign nationals who have been proven legally and convincingly of committing criminal offenses based on court verdicts, are the reflection and implementation of Indonesian criminal 
jurisdiction. Consequently, the law enforcement process and the execution of court decisions can not be interfered by anyone and under any circumstances.

\section{Execution Postponement: Implementation of Retribution Theory vs.}

\section{HumanRights Violations}

Throughout the past two years, executions are carried out in succession beneath JokoWidodo's presidential period. It was first begun withthe first stage execution in January $18^{\text {th }}, 2015$, then the secondstage execution in April29 $9^{\text {th }}, 2015$, and followed by the last one, the third stage executionin July $29^{\text {th }}, 2016$. Majority of death row inmatesinvolved innarcotic cases,were foreigners. Interestingly, not all convicts were executed. Most of the execution delayed arebased on various considerations. One of the interesting casesis the case of Mary Jane Fiesta Veloso.

At first, Mary Jane Fiesta Velosowas examined by police officers under Directorate of Drugs - Special Region Police of Yogyakartaafter being caught by security officers atAdisucipto Airport. Mary Jane was arrested for carrying 2611 grams of first category narcotics, as officially idenfitied as Heroin. Based on the facts in the trial, she wasallegedly as an intermediary in international narcotics trade between Christine in Kuala Lumpur, Malaysia and John (Prince Fatu) in Indonesia. In the trial process, she was prosecuted to life imprisonment by prosecutoron September $28^{\text {th }}, 2010$ for violation of Article 114 paragraph (2) of the Law on Narcotics.

Article 114 paragraph (1) of the Law on Narcotics

"Everyone who without rights or unlawfully offers for sale, sells, purchases, receives, be an intermediary in the sale and purchase, exchanges, or submits of first category narcotics, shall be punished with imprisonment for life orimprisonment of five (5) years and maximum of 20 (twenty) years and fined at least $1,000,000,000.00$ (one billion rupiah) and at most 10,000,000,000.00 (ten billion rupiah)."

Article 114 paragraph (2) of the Law on Narcotics

"In terms of the act offers for sale, sells, buys, be an intermediary in the sale and purchase, exchanges, gives, or receivesof first category narcoticsas referred to the paragraph (1) in the form of plantsweighs more than 1 (one) 
kilogram or exceeding 5 (five) trunks or in the form of non plant weighs five (5) grams, the offender shall be punished by death sentence, life imprisonment or imprisonment of at least 6 (six) years andmaximum of 20 (twenty) years andmaximum fine as referred to the paragraph (1) plus $1 / 3$ (one third)."

Unfortunately, the panel of judges in Sleman District Court throughVerdict No.385/ Pid.B/2010/PN.SLMN on October $11^{\text {th }}, 2010$ convicted heavier than the demands of the prosecutor: the death penalty. Although the defendant's appeal was accepted, Yogyakarta High Court through Verdict No.131/PID/2010/PTY on December $23^{\text {th }}$, 2010 upheld the previous verdict in advance. Then, the defendant appealed to the Supreme Court,but it was rejected through the Supreme Court Verdict No. 987 K/Pid.Sus/2011 on May 31 ${ }^{\text {st }}$, 2011 (The Supreme Court's Verdict Number:987 K/Pid.Sus/2011, on behalf of the convict: Mary Jane Fiesta Veloso, 2011).

After taking all the stages of general remedies,Mary Jane decided to take an extraordinary legal remedy throughthe Judicial Review. Unfortunately, the Supreme Court rejected the submission of the PK on March $25^{\text {th }}, 2015$. After that, She filed for clemency to President JokoWidodo, however it was rejected and her execution day has been set officially on April29 $9^{\text {th }}, 2015$ (second stageexecution). Fortunately, the execution was postponed due to demand ofthe PhilippinesPresident Benigno Aquino after awoman alleged as trapper Mary Jane to bring heroin into Indonesia surrendered to police officer inthe Philippines.The testimony of Mary is indispensable to expose human trafficking case involved herself as a victim. After her submissionhad been rejected by the Supreme Court, Mary Jane wouldfilefor second judicial review accompanied bylatest evidenceof legal process in thePhilippines. When she would beexecuted on July $29^{\text {th }}, 2016$ (third stage execution), Yogyakarta High Prosecutor postponed again the execution. Itwas based on a comprehensive review of legal proceedings in the Philippines.

The case of Mary Janereflects an examination ofthe government's consistency in order to either enforce the death penalty or protectthe humanrights in Indonesia. In the context of criminal prosecution, it is absolutely clear that the execution is 
valid because of binding decision. On the other hand, in the context of human rights protection, that processcauses uncertainty on law enforcement for Mary Jane. If the death penalty was considered as human rights violation, then the postponement of the death penalty would more than just that. Do you agree thatthe time which was delayed by the government is one form of 'additional punishment' to the convict? Therefore, the postponement as occurred in the case above, is interesting to be researchedunder retributivist's perspective and humanrights protection.

Theoretically, criminal law islaw of special sanctions (bijzondersanctierecht)(E.Utrecht : 57). Referring to that, the criminal law can not only restrict the freedom of human beings, but also can probablytake human life (E.Utrecht : 149). Based onobjectivecriminal law (iuspoenale), Article 10 of the Criminal Code sets out some basic punishment, such as:The death penalty, imprisonment, fines, and cover penalty. In addition, there are several additional penalties that can be imposed simultaneously with the principal penalty, such as: revocation of certain rights, deprivation of certain goods, and notices for the judge's decision. In order to implement these punishments, based on subjective criminal law (iuspoenendi), the right to prosecute, examine, and execute the punishmentsare given to the state (through the instrumentality of the government) (P.A.F. Lamintang, 2011:4).

Inessence, the death penalty imposition is a form of punishment arising from the theory of retribution. Although Indonesian criminal law system has already changedfrom the retaliation purpose to the mixing-purpose, a discussion of the theory of retribution is strongly fascinating if it was associated with death penalty. Herbart claimed that the theory of retribution is based onprinciple "If the crime was not responded, then there would ariseunsatisfiedfeelings." Retributive approach tends to revenge and retaliation. In contrast,Beccariathought that the purpose of punishment is to create a better society, not revenge (Mike C. Materni, 2013:270). 
"The purpose of punishment ... is none other than to Prevent the criminal fresh from doing harm to our fellow citizens and to Deter others from doing the same. Therefore, Punishments and the method of inflicting them must be chosen such that, in keeping with proportionality, they will the make the most efficacious and lasting impression on the minds of men with the least torment to the body of the Condemned ".

The retributiveperspective has a long history in scopeof law and philosophy. That view has the concept of proportionality as "eye to eye". For example, it is often said that the death penalty is an appropriate punishment for murderers. However, we must be careful to make necessary distinction between societies who want 'justice' and victims of crime who have a desire for 'revenge' (David L. Bender, 2004:42).

Theoretically, the concept of 'retributive punishment' akin to the concept of retribution by treating punishment as a form of retaliation to be paid by offenders. It must be highlighted that it is differentby seeing the punishment fromthe perspective of victims, perpetrators, prosecutors, and also judges. Retribution is focused on suspects' mistake,meanwhile 'revenge' is focused on the encouragement of victims (including those who are sympathetic to them) to strike back at the suspect. Ernest van den Haag stated that the theory is implemented to restore the -objective- social order, not to satisfy the desires of the -subjectivenature (revenge) (Jack P. Gibbs, Vol.69 No.03, 1978:294).

The view of the death penalty as a realization of the theory of retribution would intersect with what is described as 'the protection of human rights'. The death penalty is a kind of human rights violation of the most important one: the right to life (as a fundamental right). Fundamental rights (non-derogable rights) is a type of rights which can not be violated, reduced or restricted under any circumstances, whether it is in a state of emergency, war, including when someone becomes an inmate.

Regardless of -pros and cons- of the death penalty, the postponement of execution experienced by Mary Jane contains two important reasons.Firstly, the death sentence handed down to her is a form of 'retaliation' of the government in 
the context of the 'war on drugs' with aims of restoring public order. Secondly, in terms of human rights, Indonesian government with a strong reason, respects foreignjudicial process and the principle of -due process of law-involved of death row inmates. Besides, it would probably lighten Mary Jane's punishment if there was new evidence which shows that she is truly a victim of human trafficking. In addition, it should be underlined that the postponement of the execution indirectly violates human rights itself, in the absence of legal certainty for Mary Jane. It means, she gets 'additional punishment' to keep staying in prison untilall the process is over and the real execution day is stipulated by the government.

\section{CLOSING}

\section{Conclusion}

The imposition and execution of capital punishment against foreign nationals based on court's binding decisions, are reflection of Indonesian criminal jurisdiction.Each state regulated capital punishment, has a right to implement the execution beneath its criminal jurisdiction. In termof postponementexecution, it can be regarded as a form of 'retaliation' from the government with the aim of restoring public order orin conditions to appreciate an ongoing legal proceedings, either in scope of national or foreign jurisdiction (i.e. the Philippines). The postponement is assessed properly if it has been considered based on comprehensive reason. If the postponement is based without any apparent reason,then it will be regarded clearly as a violation of human rights. Therefore, the postponement can be interpreted that the death row inmates face capital sentence and imprisonment at once.

\section{Suggestion}

Firstly, although many countries has suppressed Indonesian government to abolish the death penalty, the president as a representation of the state must give clear description to other countries about Indonesian law enforcement particularly in term of death penalty execution.Secondly, the government must be consistent in the way to implement its jurisdiction to enforce death penalty for both nationals 
and foreign citizens. On the other hand, before a court gives the death penalty for the convicts, the government should givedeath row inmatesa chance to fulfill all their constitutional rights to have lighter punishment or forgiveness.

\section{BIBLIOGRAPHY:}

\section{Books:}

Barda Nawawi Aried, 2011, Bunga Rampai Kebijakan Hukum Pidana, Jakarta: Kencana.

E. Utrecht, Rangkaian Sari Kuliah Hukum Pidana I, tanpa kota: tanpa penerbit, tanpa tahun.

Huala Adolf, 1996,Aspek-Aspek Negara Dalam Hukum Internasional, Jakarta: RajaGrafindo Persada.

Malcolm N. Shaw, 2008, International Law : Sixth Edition, New York: Cambridge University Press.

Mochtar Kusumaatmadja \& Etty R. Agoes, 2010, Pengantar Hukum Internasional, Bandung: Alumni.

P.A.F. Lamintang, 2011, Dasar-Dasar Hukum Pidana Indonesia, Bandung: Citra Aditya Bakti.

Romli Atmasasmita, 1997, Tindak Pidana Narkotika Transnasional dalam Sistem Hukum Pidana Indonesia, Bandung: Citra Aditya Bakti.

Sanford H. Kadish, 1983, Encyclopedia of Crime and Justice, New York: the Free Press.

Sigid Suseno, 2011, Yurisdiksi Tindak Pidana Siber, Bandung: Refika Aditama.

Yudha Bhakti Ardhiwisastra, 1999,Imunitas Kedaulatan Negara di Forum Pengadilan Asing, Bandung: Alumni.

\section{Journals dan Essay}

David L. Bender, 2004, et.al,Does Capital Punishment Deter Crime?, California, Green Haven Press.

Jack P. Gibbs, 1978, The Death Penalty, Retribution and Penal Policy, the Journal of Criminal Law \& Criminology Vol.69, No.3, Northwestern University School of Law.

Mike C. Materni, 2013, Criminal Punishment and the Pursuit of Justice, Br.J.Am.Leg.Studies. 


\section{Internet}

Komisi untuk Orang Hilang dan Korban Tindak Kekerasan (KontraS), Praktek Hukuman Mati di Indonesia, makalah penelitian dan pengembangan (Litbang), 2007, hlm.22. Dapat diakses pada tautan <https://www.kontras.org/hmati/data/Working\%20Paper_Hukuman_Mati_di _Indonesia.pdf.>. diakses pada hari Senin, 26 September 2016, pada pukul 23.23 WIB

Rancangan Undang-Undang Kitab Undang-Undang Hukum Pidana (RUU-KUHP) Tahun 2013, <http://www.antikorupsi.org/sites/ antikorupsi.org /files/files/RUU\%20KUHP_2013.pdf>.diakses pada hari Senin, 26 September 2016, pada pukul 23.40 WIB

Risalah Sidang Perkara Nomor 2/PUU-V/2007 dan Perkara Nomor 3/PUUIV/2007 perihal Pengujian Undang-Undang Nomor 22 Tahun 1997 tentang Narkotika terhadap Undang-Undang Dasar 1945, Jakarta, 30 Oktober 2007. Dalam <http://www.mahkamahkonstitusi.go.id/index.php?page=download.Risalah\& id=279>, diakses pada hari Senin, 26 September 2016, pada pukul 23.34 WIB

\section{Regulations:}

The 1945 Constitution of Republic of Indonesia.

The Law Number 7 of 1997 on Ratification of United Nations Convention Against Illicit Traffic In Narcotic Drugs and Psychotropic Susdtances, 1998.

The Law Number 39 of 1999 on Human Rights.

The Law Number 26 of 2000 on Human Rights Court

The Law Number 35 of 2009 on Narcotics.

\section{Internasional Conventions}

International Covenant on Civil and Political Rights

Rome Statute of the International Criminal Court

United Nations Convention against Illicit Traffic in Narcotic Drugs and Psychotropic Substances.

\section{Verdicts}

The Supreme Court's Verdict Number 37 PK/Pid.Sus/2011, on behalf of the convict: Andrew Chan. Softcopy of the verdict is available on link $<$ http://putusan.mahkamahagung.go.id/putusan/7177ed65b8db086978d97a76 $596 \mathrm{dc} 00 \mathrm{e}>$. 
The Supreme Court's Verdict Number:987 K/Pid.Sus/2011, on behalf of the convict: Mary Jane Fiesta Veloso. Softcopy of the verdict is available on link $<$ http://putusan.mahkamahagung.go.id/putusan/029fa59d0b7e737bee0655c78 df9462a>. 